\title{
An insight into statin use and its association with muscular side effects in clinical practice
}

\author{
ANDREEA FARCAS ${ }^{1}$, CAMELIA BUCSA $^{1}$, D. LEUCUTA ${ }^{2}$,

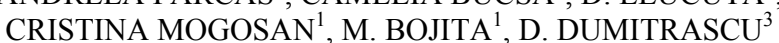 \\ ${ }^{1}$ Drug Information Research Center, "Iuliu Hațieganu” University of Medicine and Pharmacy, \\ Pasteur 6, Cluj-Napoca, Romania \\ ${ }^{2}$ Department of Medical Informatics and Biostatistics, "Iuliu Hațieganu”, University of Medicine \\ and Pharmacy, Pasteur 6, Cluj-Napoca, Romania \\ ${ }^{3} 2^{\text {nd }}$ Medical Department, "Iuliu Hațieganu" University of Medicine and Pharmacy, \\ Clinicilor 3-5, Cluj-Napoca, Romania
}

\begin{abstract}
Background. Muscular complaints are known side-effects of statin therapy, ranging from myalgia to clinically important myositis and rhabdomyolysis. We investigated the statin use and association with the presence and characteristics of muscular complaints.

Methods. We conducted a prospective observational study in internal medicine departments. Patients with statin therapy before hospitalization were interviewed for muscular complaints. When muscular complaints were reported, information on type and severity of muscular symptoms, location and time to onset was collected.

Results. We identified 85 patients with statin treatment at hospital admission out of 521 included. Nine $(10.59 \%)$ patients reported muscular complaints associated with statin therapy. A cluster of symptoms (cramps, stiffness, decreased muscle power) was reported, affecting both upper and lower limbs. The severity of pain was in most of the cases moderate or severe. All patients reported that pain was intermittent. Five reported that pain was generalized. Symptoms appeared in the first month of treatment or three months after the drug initiation. Creatine kinase was raised in one patient. In two cases drug interactions were probably responsible for muscular complaints.

Conclusion. In the studied set of patients muscular symptoms were a rather frequent effect of statin therapy. As this side-effect could be troublesome for patients and could lead to more severe outcomes, their timely detection and management is important.
\end{abstract}

Keywords: statins, myopathy, muscular side-effects.

\section{INTRODUCTION}

Numerous studies have demonstrated the benefits of 3-hydroxy-3-methyl-glutaryl (HMG)Co-enzyme-A reductase inhibitors (statins) in lowering low-density lipoprotein (LDL)-cholesterol and thereby reducing vascular events and prolonging patients' survival, therefore being now widely and effectively used [1-6]. Since their introduction almost three decades ago, in 1987, large clinical trials and post marketing experience have demonstrated that these agents are generally well tolerated if used at low and moderate doses, even in case of long-term therapy [3,6-8]. Nevertheless, statin treatment can be associated with a range of adverse events, especially various forms of myopathy, presented clinically either like muscle pains (myalgia) and/or elevated creatine kinase (CK) levels, and asymptomatic increases in hepatic transaminases [9].
The overall risk of adverse events was reported to be increased by $40 \%$ comparing to placebo in meta-analyses, especially at high doses $[10,11]$. In randomized clinical trials, the incidence of myopathy is reported in 0.5 to $5 \%$ of patients from statin and placebo groups alike, whereas in real world these percentages are much higher [9,12-14]. Observational studies reflecting real clinical practice outlined frequencies of statin myopathy ranging from $9 \%$ to $20 \%[15,16]$.

Serious adverse events such as clinically important myositis (muscle symptoms with CK elevations) and rhabdomyolysis (CK increase $>10$ times the upper limit of normal [ULN] accompanied by myoglobinuria and evidence of target organ damage such as renal failure) have also been reported, but are considered rare [17].

The myopathy associated with statin therapy is dose related [11,18]. With intensive statin therapy the risk of related adverse effects is likely 
to increase. Myopathy symptoms usually subside after drug discontinuation, but they frequently return on rechallenge $(95 \%$ of patients have a return of symptoms when restarting therapy at the same dose, 55\% when restarting at a lower dose) [11]. Among predisposing factors for statin myopathy are advanced age ( $>65$ years), smoking, BMI $>24 \mathrm{~kg} / \mathrm{m}^{2}$, renal and hepatic disorders, hypothyroidism, family history of muscular symptoms, heavy exercise and consumption of more than 1 liter of grapefruit juice per day $[19,20]$. The risk of CK increase seems to be different among statins. Under experimental conditions cerivastatin was demonstrated to have the greatest risk, followed by fluvastatin, atorvastatin, simvastatin and pravastatin, with cerivastatin being withdrawn from the market in 2001 [21].

Combining statins with agents that share common metabolic pathways also increases the risk of myopathy. Several drug interactions are of particular concern, especially the ones with drugs that inhibit the CYP3A4 metabolic pathway [22]. The metabolism of simvastatin, atorvastatin and lovastatin depends heavily on CYP3A4 and is therefore susceptible for interaction with cyclosporine and other immunosuppressive agents, with macrolide antibiotics and antifungal azoles, with calcium channel blockers. However, the remaining statins are either metabolized through different pathways (fluvastatin) or are eliminated unchanged (pravastatin and rosuvastatin), posing a lower risk for the above drug interactions, being a suitable alternative for patients that need long term therapy with these drugs [22,23].

Having all these risk factors and potential drug interactions in mind we conducted a prospective observational study to investigate the statin use and their association with muscular complaints and the characteristics of these muscular complaints.

\section{MATERIALS AND METHODS}

The study is an observational prospective study that was conducted for 8 weeks in the period November 2014 - January 2015 in two internal medicine departments with a total bed capacity of 100 patients. We included all adult patients whose medical charts were available for review on each Tuesday of the study weeks and had a documented statin treatment before hospitalization. For patients with statin treatment the information collected from patients charts included age and sex, main reason for the hospitalization, active diagnoses, data on renal and hepatic function, history of alcohol intake and smoking habits, all drugs administered (including self-medication) before hospitalization with their respective doses and duration of therapy, available clinical and biological data of interest (CK, hepatic transaminases values, creatinine and urea), and length of hospital stay. Each patient with statin therapy before hospitalization was interviewed for muscular complaints if the patient condition permitted interview. When muscular complaints reported, a questionnaire developed after Franc S. and collaborators [16] was completed in the presence of the patient. The questionnaire provides information on type and severity of muscular symptoms, location, time to onset, and management of the symptoms.

The Ethics Committee of the Medicine and Pharmacy University in Cluj-Napoca approved the study protocol. Interviewed patients were asked for informed consent. Qualitative data were presented as frequencies and percentages. Quantitative data was presented as means and standard deviations for normally distributed data, and medians, interquartile ranges or ranges for non-normally distributed data, and comparisons between two groups were made with independent samples t-test and Mann Whitney $\mathrm{U}$ test respectively. For all tests the two tail $\mathrm{p}$ value was used with a 0.05 value as level of significance. All statistical analyses were conducted in $\mathrm{R}$ environment for statistical computing and graphics, version 3.1.2.

\section{RESULTS}

We reviewed 521 medical charts and we identified 85 patients with statin treatment at hospital admission. Forty six $(54.12 \%)$ patients were on atorvastatin therapy, $24(28.23 \%)$ on rosuvastatin, $14(16.47 \%)$ on simvastatin, and 1 on lovastatin therapy. Most of these patients were prescribed 10 and $20 \mathrm{mg}$ doses, except 2 atorvastatin, 1 rosuvastatin, and the lovastatin patients that were prescribed a $40 \mathrm{mg}$ dose. Almost half (48.23\%) of the patients in this study were elderly, $56.48 \%$ being male. The majority of patients were hospitalized primarily for cardiovascular diseases, this being also the most frequent co-morbid condition, followed by metabolic and endocrinological diseases. Musculoskeletal diseases affected almost half of the patients in the present study and hepatic and renal disease half and a third of them, respectively. Six (7\%) patients had hypothyroidism documented in their charts. Patients' characteristics are presented in Table 1. 
Most of concomitant medication was cardiovascular as presented in Table 2. No antibiotics or antifungals were present in the patients' therapy at admission. Five of the patients were with selfmedication as revealed in the patients' interviews. Drug interactions were checked with Micromedex Drug Interactions program. Twenty six (30.59\%) patients had one or two potential drug interactions in their therapy.

A total of eleven patients reported muscular complaints. After reviewing their charts and pathology and excluding any alternative cause (e.g. rheumatologic conditions) we considered that in 9 cases $(10.59 \%)$ the muscular complaints were associated with the statin therapy. In this small group, 6 of the patients reporting muscular pain were men. Out of these 9 patients, 4 had drugs interacting in their therapy, but only in 2 cases the interactions could have led to muscular adverse reactions: the interaction between atorvastatin and fenofibrate in one patient and the interaction between simvastatin and colchicine in another patient. Only 3 patients had their CK measured and one had a raised value (two times the upper normal limit). The laboratory parameters are presented in Table 3. One patient with muscular complaints had hypothyroidism.
Out of 9 patients with statin associated muscular pain 6 were physically active, doing some kind of physical activity or work. Five patients reported that pain was generalized; all patients reported that pain was intermittent. A cluster of symptoms (cramps, stiffness, decreased muscle power) was reported by 5 patients, including a sensation of muscle rupture reported by one patient. Most often, both upper and lower limbs were involved. The severity of pain was considered in most of the cases as being moderate or severe. Out of the patients that could report on the time to onset of the muscular symptoms, 3 reported that symptoms appeared in the first month of treatment, and 3 reported pain three months after the drug initiation. None of these patients were aware of a family history of muscular symptoms, and none were consuming grapefruit juice. Five of 9 patients were taking analgesics for the pain, and 5 of them are constantly reading the patient information leaflets. Three patients also reported that they 'feel depressed'. A physician was consulted for these muscular complaints by 3 patients of the total 9 . Data on muscle pain characteristics are summarized in Table 4.

Table 1

Patients' characteristics

\begin{tabular}{|l|c|}
\hline \multicolumn{1}{|c|}{ Patient characteristics } & $n(\%)$ \\
\hline Sex, Female & $37(43.52)$ \\
\hline Age, years (median, [range]) & $65.58[47-88]$ \\
\hline Elderly patients ( $\geq 65$ years) & $41(48.23)$ \\
\hline Hospital stay, days (median, [range]) & $7.74[3-36]$ \\
\hline Alcohol consumption (Yes) & $15(17.64)$ \\
\hline Smoking (Yes) & $24(28.23)$ \\
\hline Main reason for hospitalization & $22(25.88)$ \\
\hline Left ventricular dysfunction & $14(16.47)$ \\
\hline Heart failure & $7(8.23)$ \\
\hline Hypertension & $5(5.88)$ \\
\hline Chronic obliterative arteriopathy of the inferior limbs & $4(4.70)$ \\
\hline Hepatic steatosis & $4(4.70)$ \\
\hline Gastritis & $858(20.18[0-24])$ \\
\hline Co-morbidities, total (median, [range]) & $82(96.47)$ \\
\hline Cardiovascular & $69(81.17)$ \\
\hline Metabolic and endocrinological & $31(36.47)$ \\
\hline Gastrointestinal & $29(34.11)$ \\
\hline Renal & $43(50.59)$ \\
\hline Hepatic & $22(25.88)$ \\
\hline Respiratory & $41(48.23)$ \\
\hline Musculoskeletal & $20(23.53)$ \\
\hline Psychiatric and neurological & $11(12.94)$ \\
\hline Ophthalmologic & $6(7.06)$ \\
\hline Dermatologic & $15(17.65)$ \\
\hline Cancer & \\
\hline$n=$ number of patients in a given category & \\
\hline
\end{tabular}


Table 2

Most frequently prescribed drug classes in patients on statin therapy

\begin{tabular}{|l|c|}
\hline \multicolumn{1}{|c|}{ Drug class } & $n(\%)$ \\
\hline RAS acting agents & $63(74.12)$ \\
\hline Beta-blockers & $58(68.23)$ \\
\hline Diuretics & $46(54.12)$ \\
\hline Antiplatelet drugs & $45(52.94)$ \\
\hline Calcium channel blockers & $22(25.88)$ \\
\hline Antidiabetics & $21(24.70)$ \\
\hline Proton pump inhibitors & $18(21.18)$ \\
\hline Anticoagulants & $15(17.64)$ \\
\hline Anxiolitics & $11(12.94)$ \\
\hline NSAIDs & $9(10.59)$ \\
\hline Digoxin & $7(8.23)$ \\
\hline Fibrates & $5(5.88)$ \\
\hline Antiarrhythmics & $5(5.88)$ \\
\hline RAS- renin angiotensin system; NSAIDs - nonsteroidal anti-inflammatory drugs \\
\hline
\end{tabular}

Table 3

Laboratory values for patients with statin therapy

\begin{tabular}{|l|c|c|c|}
\hline & $\begin{array}{c}\text { Without muscular symptoms } \\
(\mathrm{n}=74)\end{array}$ & $\begin{array}{c}\text { With muscular symptoms } \\
(\mathrm{n}=11)\end{array}$ & P-value \\
\hline Creatine kinase, median (IQR) & $70(67-305)$ & $82.5(64.25-106)$ & 0.78 \\
\hline Aspartate aminotransferase, median (IQR) & $24.5(20.5-27)$ & $22(18-28)$ & 0.44 \\
\hline Alanine aminotransferase, median (IQR) & $25.04[6-170]$ & $23.40[9-50]$ & 0.81 \\
\hline Creatinine, median (IQR) & $1.15(0.93-1.24)$ & $1.07(0.9-1.42)$ & 0.77 \\
\hline Urea, median (IQR) & $32.8(26.8-45.4)$ & $43.8(30.75-57.08)$ & 0.08 \\
\hline Total cholesterol, mean (SD) & $191.45(52.33)$ & $188(49.13)$ & 0.83 \\
\hline Triglycerides, median (IQR) & $132(120.5-199)$ & $111.5(79.75-157.25)$ & 0.08 \\
\hline IQR= interquartile range; SD=standard deviation \\
\hline
\end{tabular}

Table 4

Muscle pain characteristics

\begin{tabular}{|l|c|}
\hline \multicolumn{1}{|c|}{ Characteristic } & Number of patients \\
\hline Pain & 4 \\
\hline Localized & 5 \\
\hline Generalized & 9 \\
\hline Intermittent & \\
\hline Localization of pain & 6 \\
\hline Upper limbs & 8 \\
\hline Lower limbs & 5 \\
\hline Arms/ forearms & \\
\hline Triggering factors & 7 \\
\hline Physical exercise & 4 \\
\hline Resting or lying down & 2 \\
\hline Cold/Flu & 4 \\
\hline Type of pain & 8 \\
\hline Cramps & 4 \\
\hline Muscular weakness or loss of strength & \\
\hline Stiffness & 2 \\
\hline Severity & 3 \\
\hline Mild & 4 \\
\hline Moderate & 3 \\
\hline Severe & 3 \\
\hline Time to onset & \\
\hline$<1$ 1month & \\
\hline$>3$ months & \\
\hline
\end{tabular}




\section{DISCUSSION}

Muscle pain as a side effect of statin therapy is a well-documented adverse reaction along with myopathy, rhabdomyolysis and increased liver enzymes. Since statins availability on the market, reports of these adverse reactions were non infrequent. Despite this and despite the fact that muscle pain not detected on time can lead to aggravation and serious consequences, these adverse reactions of statins can easily pass unrecognized as muscle aches are also common in untreated patients. The statins product information recommends that patients are asked to report new or unexplained muscle pain, but this is an information that should reach the patient in order for them to be aware and report on time; this of course depends on patients to read the product information leaflet or on treating physicians to inform the patients on possible adverse drug reactions.

Although several studies from Western European countries described the clinical characteristics of muscle symptoms in their set of patients [16, 24-27], in Romania these data are missing as per our knowledge. The present study, although small in numbers, offers an insight into statin use in real clinical practice and its association with muscular symptoms. Moreover, we have investigated the characteristics and risk factors of muscle symptoms starting from the current knowledge on these adverse reactions.

A cross-sectional study in primary care found that up to $44 \%$ of patients with lipid-lowering drugs experienced muscular complaints [26]. The PRIMO study, that thoroughly investigated muscular symptoms, found that $10.5 \%$ of the patients on high-dosage statin therapy reported muscle pain [25]. We found a similar percentage of patients $(10.6 \%)$ complaining of muscle pain in our study, but the statin doses were low (10 and $20 \mathrm{mg}$ ) except in one patient. However, one might keep in mind that our sample of assessed patients is smaller than in other studies and the frequency of muscular events was not a primarily goal of this study.

A family history of muscle symptoms is one of the risk factors for statin-induced myopathy [16]. In our study, patients presenting muscle pain responded that they were not aware of family members experiencing muscle symptoms. Renal and hepatic insufficiency are among common risk factors for muscle toxicity too. Although in the overall population there were patients with renal and hepatic diseases, our results did not show a statistically significant difference of the median values of creatinine, urea and liver enzymes between patients with and without muscular side effects. Moreover, our results did not show a statistically significant difference of the CK median values between patients with and without muscular pain, despite the fact that elevated $\mathrm{CK}$ is a significant risk factor for statin induced myopathy. Notwithstanding, there are previous reports and experience where most of the patients that develop weakness and pain on statin therapy present with normal CK levels, as muscle symptoms might represent a muscle toxicity below the threshold to increase CK [20,28]. Moreover, CK was assessed only in a few patients with muscular symptoms in our study.

Most patients described muscular pains as muscular weakness or loss of strength and half of them as cramps or stiffness. This is contrary to the findings of the PRIMO study where more than half of the patients described the type of pain as heaviness/stiffness or cramps [25]. However, patients in the PRIMO study were with high-dosage statin therapy that could lead to more severe symptoms. Also in the PRIMO study, pain was widespread in the majority of patients; in our study pain was generalized in only half of the patients. Pain was most often intermittent and affected the lower limbs in our and in PRIMO study. Patients in the PRIMO study reported that tights and calves were the ones affected [25].

Duration of statin therapy before the onset of muscular pain may vary from a few weeks to more than 2 years [29]. Franc et al. and PRIMO study reported that time to onset of muscular pain is usually 1 month following initiation of the statin therapy, with another peak observed after 12 months of treatment $[16,25]$. We also found that the $1^{\text {st }}$ month was the time of onset for muscular symptoms. Physical exercise was the most commonly reported triggering factor in our study and in the PRIMO study as well [25].

\section{A WORD ON STATIN-FIBRATE COMBINATION THERAPY}

Statin-fibrate combination therapy is relatively frequent in clinical practice as it offers clear advantages over monotherapy due to the fact that patients with mixed hyperlipidemia can rarely be successfully treated with a single agent. However, due to the drug interaction between fibrates and statins, patients on combination therapy are also 
exposed to greater myopathy and rhabdomyolysis risk than patients on monotherapy. Moreover, fibrate monotherapy is an independent risk factor for myopathy, current fibrate users being 5.5 times more likely to develop myopathy than current statin users $[23,30]$. All fibrates have been associated with $\mathrm{CK}$ elevations and myopathy when combined with statins, but the risk seems higher for gemfibrozil use, compared to bezafibrate and fenofibrate use [23]. Furthermore, the risk is higher in elderly patients, in patients with renal and hepatic disease, and other severe illness, and in patients with multiple medications. In our case the patient with the atorvastatin - fenofibrate association was not elderly, but had severe hepatopathy. CK levels were not available, but the patient presented moderate to severe lower limbs pain.

\section{LIMITATIONS}

This is a small-scale study and it should be regarded as such, without generalizing its results in larger population. Due to the small patient number, myopathy risk associated to individual statins could not be assessed. The questionnaires usedrely only on patients' inter- pretation of pain, without any other objective confirmation for the described symptoms (CK was not assessed in all patients with muscular complaints). However questionnaires were applied and filled in by the study team in order to avoid any misunderstanding or misinterpretation of the questions by the patients and to have a most objective image.

\section{CONCLUSIONS}

Our results emphasized that in this studied set of patients, muscular symptoms are a rather frequent effect of statin therapy. Although this typically reversible effect is troublesome for patients, it may go overlooked and unreported in many of them, especially if mild muscular symptoms, unless specific questions are addressed to patients. As there is no simple way to ensure causal relationship between a certain drug and an event, having in mind the muscle pain characteristics and the risk factors highlighted in this study could help identifying statin induced muscular adverse reactions.

Acknowledgments. We want to thank master students Adela Adamescu and Flavia Cuibus for their involvement in the study.

Introducere. Afectarea musculară este o bine cunoscută reacție adversă a terapiei cu statine, variind de la mialgie la miozita şi rabdomioliza importante clinic. Am evaluat utilizarea statinelor şi asocierea cu prezența şi caracteristicile afectărilor musculare.

Metoda. Studiul pe care l-am efectuat în departamentele de medicină internă a fost prospectiv observațional. Am chestionat pacienții care aveau tratament cu statine inainte de spitalizare cu privire la simptomele musculare. Atunci când au fost raportate simptome musculare am notat informația $\mathrm{cu}$ privire la tipul şi severitatea simptomelor, localizarea şi momentul debutului.

Rezultate. Din cei 521 de pacienți incluşi am identificat 85 pacienți cu tratament cu statine la internarea în spital. Nouă pacienți (10.59\%) au avut simptome musculare asociate terapiei cu statine. A fost raportată o grupare de simptome care afectau atât membrele superioare, cât şi cele inferioare (crampe, redoare, scăderea forței musculare). Severitatea durerii în majoritatea cazurilor a fost moderată sau severă. Toți pacienții au raportat durerea ca fiind intermitentă. Cinci pacienți au raportat durerea ca fiind generalizată. Simptomele au apărut în prima lună sau în primele trei luni de la inițierea tratamentului. Creatinkinaza a avut valori crescute la un pacient. In două cazuri pentru simptomele musculare interacțiunile medicamentoase au fost probabil responsabile.

Concluzie. In lotul de pacienți studiat simptomele musculare au fost un efect frecvent al terapiei cu statine. Deoarece această reacție adversă poate fi neplăcută pentru pacienți şi poate avea o evoluție mai severă, este importantă detectarea şi managementul din timp al acesteia. 
Corresponding author: Farcas Andreea, Axente Sever 39, 400428 Cluj-Napoca, Romania Phone +40 0724 238587, Fax +40264 430368

E-mail: afarcas@umfcluj.ro

Grant support: This paper was published under the frame of European Social Fund, Human Resources Development Operationl Programme 2007-2013, project no. POSDRU/159/1.5/136893

Conflicts of interest: none.

\section{REFERENCES}

1. BAIGENT C, KEECH A, KEARNEY PM, BLACKWELL L, BUCK G, POLLICINO C, et al. Efficacy and safety of cholesterol-lowering treatment: prospective meta-analysis of data from 90,056 participants in 14 randomized trials of statins. Lancet 2005; 366:1267-1278.

2. SHEPHERD J, COBBE SM, FORD I, ISLES CG, LARIMER AR, MACFARLANE PW, et al., for the West of Scotland Coronary Prevention Study Group. Prevention of coronary heart disease with pravastatin in men with hypercholesterolemia. New Engl J Med 1995; 333:1301-7.

3. Scandinavian Simvastatin Survival Study Group. Randomized trial of cholesterol lowering in 4444 patients with coronary heart disease: the Scandinavian Simvastatin Survival Group. Lancet 1994; 344:1383-9.

4. KOLOVOU G. The treatment of coronary heart disease. An update. Part 3: Statins beyond cholesterol lowering. Current Med Res and Opinion 2001; 17:34-7.

5. The Long-Term Intervention with Pravastatin in Ischaemic Disease (LIPID) Study Group. Prevention of cardiovascular events and death with pravastatin in patients with coronary heart disease and a broad range of initial cholesterol levels. $\mathrm{N}$ Engl $\mathrm{J}$ Med 1998; 339(19):1349-1357.

6. BRADFORD RH, SHEAR CL, CHREMOS AN, DUJOVNE CA, FRANKLIN FA, GRILLO RB, et al. Expanded Clinical Evaluation of Lovastatin (EXCEL) study results: two-year efficacy and safety follow-up. Am J Cardiol 1994; 74(7):667-673.

7. STEINHAGEN-THIESSEN E. Comparative efficacy and tolerability of 5 and $10 \mathrm{mg}$ simvastatin and $10 \mathrm{mg}$ pravastatin in moderate primary hypercholesterolemia. Simvastatin Pravastatin European Study Group. Cardiology 1994; 85(3-4):244-254.

8. BERTOLINI S, BON GB, CAMPBELL LM, FARNIER M, LANGAN J, MAHLA G, et al. Efficacy and safety of atorvastatin compared to pravastatin in patients with hypercholesterolemia. Atherosclerosis 1997; 130(1-2):191-197.

9. ARMITAGE J. The safety of statins in clinical practice. Lancet 2007; 370:1781-1790.

10. SILVA MA, SWANSON AC, GANDHI PJ, TATARONIS GR. Statin related adverse events: A meta-analysis. Clin Ther. 2006; 28:26-35.

11. SILVA M, MATTHEWS ML, JARVIS C, NOLAN NM, BELLIVEAU P, MALLOY M, et al. Meta-analysis of drug-induced adverse events associated with intensive-dose statin therapy. Clin Ther. 2007; 29(2):253-60.

12. THOMPSON PD, CLARKSON P, KARAS RH. Statin-associated myopathy. JAMA 2003; 289(13):1681-1690.

13. PASTERNAK RC, SMITH SC JR, BAIREY-MERZ CN, GRUNDY SM, CLEEMAN JI, LENFANT C. ACC/AHA/NHLBI clinical advisory on the use and safety of statins. J Am Coll Cardiol 2002; 40:567-572.

14. KASHANI A, PHILLIPS CO, FOODY JM, WANG Y, MANGALMURTI S, KO DT, et al. Risks associated with statin therapy: a systematic overview of randomized clinical trials. Circulation 2006; 114:2788-2797.

15. DE SAUVAGE NOLTING PR, BUIRMA RJ, HUTTEN BA, KASTELEIN JJ. Two-year efficacy and safety of simvastatin 80 $m g$ in familial hypercholesterolemia (the Examination of Probands and Relatives in Statin Studies with Familial Hypercholesterolemia [ExPRESS FH]). Am J Cardiol 2002; 90:181-184.

16. FRANC S, DEJAGER S, BRUCKERT E, CHAUVENET M, GIRAL P, TURPIN G. A comprehensive description of muscle symptoms associated with lipid-lowering drugs. Cardiovasc Drugs Ther 2003; 17:459-465.

17. GRAHAM DJ, STAFFA JA, SHATIN D, ANDRADE SE, SCHECH SD, LA GRENADE L, et al. Incidence of hospitalized rhabdomyolysis in patients treated with lipid-lowering drugs. JAMA 2004; 292(21): 2585-2590.

18. The SEARCH Collaborative Group. SLCO1B1 variants and statin induced myopathy - a genomwide study. N Engl J Med 2008; 359(8):789-799.

19. SINZINGER H, WOLFRAM R, PESKAR BA. Muscular side effects of statins. J Cardiovasc Pharmacol. 2002; 40(2):163-71.

20. FERNANDEZ G, SPATZ ES, JABLECKI C, PHILLIPS PS. Statin myopathy: a common dilemma not reflected in clinical trials. Cleve Clin J Med. 2011; 78(6):393-403.

21. NAKAI A, NISHIKOTA M, UCHIDA T, ICHIKAWA M, METSUYAMA K. Enhanced myopathy following administration of hypolipidemic agents under methane anesthesia. Chem Pharm Bull 997; 20:104-6.

22. ROWAN CG, BRUNELLI SM, MUNSON J, FLORY J, REESE PP, HENNESSY S, et al. Clinical importance of the drug interaction between statins and CYP3A4 inhibitors: a retrospective cohort study in The Health Improvement Network. Pharmacoepidemiol Drug Saf. 2012; 21(5):494-506.

23. BALLANTYNE CM, CORSINI A, DAVIDSON MH, HOLDAAS H, JACOBSON TA, LEITERSDORF E, et al. Risk for myopathy with statin therapy in high-risk patients. Arch Intern Med. 2003; 163(5):553-64.

24. DUGUÉ A, BAGHERI H, LAPEYRE-MESTRE M, TOURNAMILLE JF, SAILlER L, DEDIEU G, et al. Detection and incidence of muscular adverse drug reactions: a prospective analysis from laboratory signals. Eur J Clin Pharmacol. 2004; 60(4):285-92. 
25. BRUCKERT E, HAYEM G, DEJAGER S, YAU C, BÉGAUD B. Mild to moderate muscular symptoms with high-dosage statin therapy in hyperlipidemic patients - the PRIMO study. Cardiovasc Drugs Ther. 2005; 19(6):403-14.

26. MOSSHAMMER D, LORENZ G, MEZNARIC S, SCHWARZ J, MUCHE R, MÖRIKE K. Statin use and its association with musculoskeletal symptoms--a cross-sectional study in primary care settings. Fam Pract. 2009; 26(2):88-95.

27. HEDENMALM K, ALVAN G, OHAGEN P, DAHL ML. Muscle toxicity with statins. Pharmacoepidemiol Drug Saf. 2010; 19(3):223-31.

28. PHILLIPS PS, HAAS RH, BANNYKH S, HATHAWAY S, GRAY NL, KIMURA BJ, et al. Statin-associated myopathy with normal creatine kinase levels. Ann Intern Med. 2002; 137(7):581-5.

29. CORSINI A. Statin-related muscle complaints: an underestimated risk. Cardiovasc Drugs Ther. 2005; 19(6):379-81.

30. GAIST D, RODRÍGUEZ LA, HUERTA C, HALLAS J, SINDRUP SH. Lipid-lowering drugs and risk of myopathy: a population-based follow-up study. Epidemiology 2001; 12(5):565-9. 